\title{
Perceived Ethnic Discrimination and School Connectedness among Adolescents in Finland: Role of Family Background and Sex
}

\author{
Isik Zeliha Ulubas \\ Department of Developmental \\ Psychology, \\ Åbo Akademi University \\ isik.ulubas@abo.fi
}

\author{
Kaj Björkqvist \\ Department of Developmental \\ Psychology, \\ Åbo Akademi University \\ kaj.bjorkqvist@abo.fi
}

\author{
Patrik Söderberg \\ Department of Developmental \\ Psychology, \\ Åbo Akademi University \\ patrik.soderberg@abo.fi
}

\begin{abstract}
The study investigates the effect of immigrant background and sex on perceived ethnic discrimination and school connectedness in Finland. An online questionnaire was completed by I,827 adolescents (12-19 years of age) from both Finnish and Swedish speaking schools in Western Finland. Adolescents' family background was categorized as either native, multicultural, or immigrant. Perceived ethnic discrimination was examined according to its source, whether it acted out by peers, by teachers, or by someone else. Adolescents with an immigrant background were found to have higher scores of perceived ethnic discrimination regardless of its source, and lower school connectedness than other groups. Boys had higher scores of perceived ethnic discrimination by peers and by someone else, and they also reported higher school connectedness than girls. There was also a significant interaction effect between immigrant background and student sex, so that girls with a multicultural background experienced higher levels of discrimination by peers and discrimination by someone else than boys with a multicultural background.
\end{abstract}

Keywords: Perceived ethnic discrimination; school connectedness; immigrant background; adolescents.

Received I5 February 202I/Accepted 9 June 202I @Author all rights reserved

\section{Introduction}

Perceived ethnic discrimination (PED), defined as "unfair treatment that a person attributes to his or her ethnicity" (Contrada et al., 2000, p. 136), has emerged as an essential factor for immigrant adolescents' social attitudes and well-being in school (Huynh \& Fuligni, 2010; Wong, Eccles, \& Sameroff, 2003). Increasing immigration has raised the focus on acculturation of youth in Europe. Acculturation is commonly defined as influence of cultural groups over each other during the period of contact (Berry, Poortinga, Breugelmans, Chasiotis, \& Sam, 20II), and, therefore, a positive social environment is essential for developing healthy inter-group relations. Primary and secondary school plays a central role in the acculturation process of adolescents (Vedder \& Horenczyk, 2006), especially for those 
with an immigrant background. Adolescents who experience themselves as separated from the majority have been found to perceive more ethnic discrimination compared to those who show positive attitudes towards integration or assimilation (Jasinskaja-Lahti, Liebkind, Horenczyk, \& Schmitz, 2003).

Bronfenbrenner's socio-ecological model(2006) presents a person-centered design with five embedded environmental systems (micro, meso, exo, macro, and chrono) that influences adolescents' development (Bronfenbrenner, 1994). Microsystem consists of immediate settings where face-to-face interactions occur i.e. with parents, peers, teachers and people in the neighborhood. According to this model, regular interactions for a long period of time are called proximal processes, and are seen as the most influential contributors to one's development (Bronfenbrenner, 2006). Belonging to a socially devalued group may increase the likelihood of these contexts being biased, and regular experiences of discrimination may be part of these interactions especially in the microsystem. In addition to that, Spencer, Dupree, and Hartman (1997) stresses that effect of discrimination on child's development is not only dependent on their social cognition and other risk factors but also protective factors in their lives.

Low mental well-being is one of the main negative outcomes of the challenging situation that immigrants face as residents in a new country. A meta-analysis of studies conducted in Europe found a higher risk of lower psychological well-being among adolescents with an immigrant background than among those with a native background (Dimitrova, Chasiotis, \& Van de Vijver, 2016). Moreover, perceived discrimination has been suggested as the strongest factor that affects immigrant psychological well-being (Berry, Phinney, Sam, \& Vedder, 2006), and it is more likely to be experienced by adolescents with an immigrant background than by those with a native background (Strohmeier, Kärnä, \& Salmivalli, 20I I). Furthermore, bi-ethnic/racial adolescents, especially those with an African-American background were found to perceive more discrimination than those with a native background (Herman, 2004). In the same study, higher self-esteem and positive ethnic identification neither were nor experienced as benefits among bi-ethnic/racial adolescents. On the other hand, adapting to the new culture or feeling less acculturative stress was found to have a moderating effect between perceived discrimination and low mental well-being 
(Noh \& Kaspar, 2003). The relationship between acculturation and PED is complex and not the main topic of this study, still, it might be beneficial to mention few more findings. Perceived discrimination was found to be higher among immigrant adolescents with acculturation attitudes that include cultural maintenance (integration and separation) in France, while in Canada, it was lower for those with integration attitudes (Berry \& Sabatier, 2010). Another study have found that, even though the acculturation of immigrant adolescents has improved, perceived discrimination has persisted or even increased over time (Gil, Wagner, \& Vega, 2000). Risk factors for immigrant youth's mental health include, but are not limited to, perceived ethnic/racial discrimination. Youth with an immigrant background have been found to have a lower sense of school belonging, life satisfaction, resilience, and victimization from aggression (Organization for Economic Co-operation and Development, 2018).

\section{Perceived Ethnic Discrimination as a Risk Factor for Mental Health}

Among Scandinavian youth with an immigrant background, the risk factors for mental health are similar to those within the rest of Europe. In Finland, ethnic background is one of the main causes of discrimination towards adolescents, and discriminative behaviors include unfair or negative treatment, teasing, and social rejection (Liebkind, Jasinskaja-Lahti, \& Solheim, 2004). Adolescents with a native background in Sweden were found to be more likely to avoid friendships with immigrant peers (Özdemir \& Özdemir, 2017), and adolescents with an immigrant background were more likely to be rejected in the peer environment (Plenty \& Jonsson, 2017). During adolescence, the importance of peer acceptance peaks (LaFontana \& Cillesen, 2010), and a high level of social exclusion may cause higher risks for immigrant adolescents since they are more in need of building new peer relationships than natives after immigrating to a new country. Thus, the psychological wellbeing of adolescents with an immigrant background was found to be lower than among their native peers in Sweden (Hjern et al., 20I3).

Finland is considered to be relatively slow in receiving immigrants in comparison with most other European nations. Foreign speaking residents comprise only $7.3 \%$ of the population (Statistics Finland, 2019), but the number of adolescents with an immigrant background is growing rapidly (OECD, 20I8), which means that the school environment will become more 
diverse in the near future. On the other hand, prejudiced beliefs against immigrants have been found to be common in Finland (Jaakkola, 2009; Jasinska-Lahti \& Liebkind, 200 I; Nshom \& Croucher, 2017). In a recent study, Finnish adolescents stated that discrimination is widespread (Zacheus et al., 2019), and immigrants were seen as a threat by native adolescents (Nshom \& Croucher, 2017). A few studies have found that adolescents with an immigrant background experience more discrimination than native youth (Myllyniemi, 2017; Wikström, Haikkola, \& Laatikainen, 2014), and perceived ethnic discrimination was experienced by immigrants of both the first and second generations (Myllyniemi, 2017). Exposure to discrimination was related with low self-esteem, stress symptoms, and poor school adjustment (Liebkind, Jasinska-Lahti,\& Solheim, 2004).

\section{Source of Discrimination and Effect of Sex}

Benner and Graham (2013) investigated whether the source of discrimination (i.e. by peers or teachers) had different effects on adolescents, and found that PED by peers was related to psychological maladjustment, while PED by teachers was related to poor school performance. Youth with immigrant background report more unfair treatment by teachers (OECD, 2017). On the other hand, positive relationships with teachers were found to decrease the negative effects of discrimination by peers among immigrant youth (Özdemir \& Stattin, 2014).

Some studies have investigated the effect of sex on PED, and have found that experienced discrimination may differ between boys and girls. An 18-year longitudinal study concluded that boys perceived more discrimination over time than girls did (Assari, Gibbons, \& Simons, 2018). However, even though boys were found to have higher scores on PED than girls (Assari \& Caldwell, 2017; Lorenzo-Blanco, Unger, Oshri, Baezconde-Garbanati, \& Soto, 2016), depressive symptoms were found to be more associated with PED among girls than boys (English, Lambert, \& lalongo, 20I4).

\section{School Connectedness as a Protective Factor}

School connectedness functions as a buffer against negative effects of PED, poor mental health (Oldfield, Humphrey, \& Hebron, 2016; Abubakar, Vijver, Mazrui, Murugami, \& Arasa, 20I4), and thoughts of dropping out from school (McWhirter, Garcia, \& Bines, 20I8). 
Adolescents who perceived better relationships with peers and teachers reported higher school connectedness (Chui, Pong, Mori, \& Chow, 2012; Uslu \& Gizir, 2017; Niehaus, Irvin, Rogelberg, 2016). Similarly, perceived and nominated friendship was positively related to higher school connectedness among adolescents with an immigrant background (Delgado, Ettekal, Simpkins, \& Schaefer, 2016).

Studies investigating the link between school connectedness and PED have found varying results. Weak school connectedness was found to be associated with higher PED among adolescents with an immigrant background (Liu, Yu, Wang, Zhang, \& Ren, 20I4). On the other hand, Cooper, Brown, Metzger, Clinton, \& Guthrie (2013) did not find any connection between school connectedness and PED. One reason for the mixed findings might be that the authors used different measures of school connectedness. In the study by Goodenow (1993) and Liu et al. (2014), connectedness was defined as sense of acceptance, respect, inclusion and support from peers, school personnel, and environment, while Cooper and colleagues (2013) measured school connectedness as academic commitment.

\section{Effect of immigrant background and sex on school connectedness}

An international study among adolescents from $4 \mathrm{I}$ countries found that immigrant adolescents experienced lower school connectedness compared to native adolescents (Chiu et al., 2012). Similarly, according to a longitudinal study, adolescents that partially have another ethnic/racial background than the majority were found to have lower school connectedness than their native peers (Cheng \& Klugman, 2010).Compared to native youth, the protective effect of school connectedness and teacher support on depressive symptoms was found to be notably higher among racial minority youth (Joyce \& Early, 2014). Still, adolescents with an immigrant background have been found to report on average less support at school than natives (Gregory \& Weinstein, 2008). Low school connectedness and behavioral problems were found to predict dropout rates of adolescents (Wang \& Fredricks, 2014). In Sweden, two fifth of the youth with immigrant background had dropped out from upper secondary schools, while the proportion was $22 \%$ among native students (Taguma, Shewbridge, Huttowa, \& Hoffman, 2009). Similarly, the Finnish National Agency for Education (2018) has reported that adolescents whose mother tongue is a foreign language have higher dropout rates than their native peers. Other factors, such as poor academic 
performance, low attendance, and low self-identification with school (Balfanz, Herzog, \&Mac Iver, 2007; Fall \& Robers, 20I2) predicted dropout from school among adolescents. As a family related factor, low socioeconomic status has been found to be one of the strongest predictors of dropout (Dunham \& Wilson, 2007), and children with an immigrant background report lower socioeconomic status compared to those with native background (Capps, Fix, Ost, Reardon-Anderson, \& Passel, 2005; Hernandez, 2004; Jackson, Kiernan, \& McLanahan, 20I2).

Studies investigating sex differences regarding school connectedness show mixed results. Some studies have found girls to report higher school connectedness than boys (Hughes, Im,\& Allee, 20I5; O’Neel \& Fuligni, 20I3), and that school connectedness declined later in adolescences among girls than among boys (O'Neel \& Fuligni, 20I3). On the other hand, boys have also been found to report higher levels of school connectedness than girls (Bottiani, Bradshaw, \& Mendelson, 2017).

The aim of the current study was to investigate perceived ethnic discrimination among Finnish secondary school students from diverse family backgrounds (natives, immigrants, and multicultural backgrounds). The study is novel in the sense that it explores school connectedness in relation to ethnic discrimination regarding which there is an existing research gap, and it explores the effect of three types of family background. Specifically, the study addresses the following research questions:

This study aims to investigate (I) the relationship between adolescents' family background in terms of immigration different forms of perceived ethnic discrimination (PED) and school connectedness, (2) to what extent students' sex is related to PED and school connectedness, and (3) whether or not there is an interaction effect between family background and sex on PED and school connectedness. In addition to that, multicultural youth, i.e. adolescents who have one native parent while the other is an immigrant, are also targets of study. Adolescents with multicultural family background are usually underrepresented in previous research. The reason to study adolescents as having native, multicultural and immigrant background was to emphasize the differences between these groups on the investigated variables. 


\section{Method}

\section{Participants}

The sample consisted of I,827 adolescents (996 girls, 737 boys; 24 participants described themselves as belonging to neither sex, i.e. as having another sexual orientation, and 70 preferred not to declare their sex). Participants were from ten different junior high and high schools in Western Finland. Seven of the schools were Finnish-speaking and three were Swedish-speaking schools; since this particular region in Finland is bilingual. The age of the respondents' ranged from 12 to 19 years. The mean age for girls was 15.7 years $(S D=1.6)$, for boys I5.4 (SD = I.6), for others I4.8 (SD = I.7), and for those who preferred not to say I4.9 (SD = 1.9). Those having another sexual orientation and preferred not to declare their sex were not included in the analysis where sex differences were investigated. The age difference between girls and boys was significant, although the effect size measured with Cohen's $d$ was small $\left[t_{(1731)}=4.29, p<.001, d=.02\right]$. The significant difference was apparently due to the relatively high sample size. However, age was kept as a covariate in the subsequent analyses in order to avoid possible bias due to age.

One hundred and fifty-five (8.5\%) of the adolescents were born abroad. The respondents were divided into three groups in accordance with their family background. If both parents had an immigrant background, they were recorded as having an immigrant family background. If one parent had an immigrant background and the other a native (either a Finnish- or Swedish-speaking), they were recorded as having a multicultural family background. If both parents had a native (either a Finnish-speaking or Swedish-speaking) background, the adolescents were recorded as having a native background. Of the participants, 125 (6.8\%) belonged to immigrant families, and $176(9.6 \%)$ of belonged to multicultural families in which one parent was born abroad. Reported spoken languages at home were as follows: only Finnish $(n=1242)$, only Swedish $(n=159)$, only other languages $(n=87)$, only English $(n=8)$. Two, three or even more languages were spoken at home by a significant amount of the participants. A hundred and seventy-five of the participants spoke both Finnish and Swedish at home, 4I spoke Finnish and other languages, 39 spoke Finnish and English, and 6 spoke Swedish and other languages; $5 \mathrm{I}$ spoke three or more languages at home. 
Ethical considerations

Parents or legal guardians, school officials, and municipalities were informed about the study, and study participation was voluntary for the adolescents. The study followed the principles concerning guidelines for the responsible conduct of research of The Finnish Advisory Board on Research Integrity (20I2). An information letter about the study and parental consent was provided in Finnish, Swedish and English, considering that at least one parent would be able to speak one of these languages.

\section{Measures}

The data were collected with an online questionnaire. Both direct (e.g. name-calling, insulting) and indirect forms (e.g. unfair treatment, assuming one is unintelligent) of PED is studied among youth from both immigrant and native background. PED was measured using a 27-item Likert scale consisting of three subscales measuring PED by peers, teachers, and by someone else. The items for this measure were adopted from Nadal (20II), Pachter, Bernstein, Szalacha, \& García Coll (2010), Contrada et al. (200I), and Whitbeck, Hoyt, McMorris, Chen, \& Stubben (200I). The items for the subscales of PED by peers and teachers are presented in Figure I. The response alternatives were on a five-point scale ranging from 0 (not at all) to 4 (very often). Completing the questionnaire took approximately 15 minutes, and in addition to family background and sex, information on age, country of birth, length of stay in Finland (if born abroad), language spoken at home, and the school's name were collected.

A few items were added to these items while constructing the subscale for PED by someone else, for instance 'someone avoided walking near you on the street'. The reliability was measured with Cronbach's $\alpha$, which for this scale was .93. In the case of all subscales, the total scores were divided by the number of items in the subscale, so that the range of the scale remained $0-4$. The missing data was handled with list-wise deletion since the sample was large and the percentage of missing data was low $(<5 \%)$. 
Table I

Items Included in Two of the Subscales Measuring Perceived Ethnic Discrimination by Peers and Teachers, Respectively.

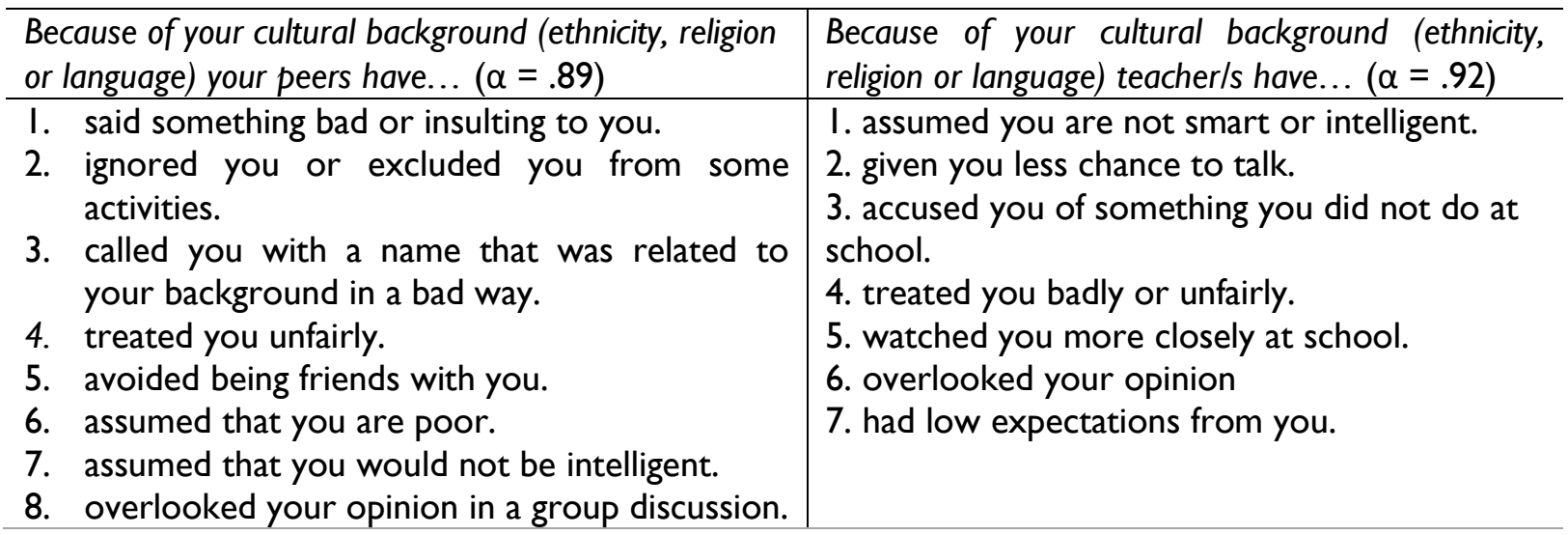

School connectedness was measured with Goodenow's (1993) Psychological Sense of School Membership Scale ( $\alpha=.89$ in the present study). This scale consisted of I2 items, i.e. 'I feel like a real part of this school' and 'People here notice when I am good at something'.

\section{Results}

The correlations between the dependent variables used in the study are presented in Table

2. As expected, the three types of perceived ethnic discrimination correlated negatively with school connectedness, and the strength of the correlation was moderate. Correlations between three forms of PED were high.

Table 2.Pearson Correlation Coefficients for Three Types of Perceived Ethnic Discrimination (PED) and School Connectedness. Correlations for Boys are above the Diagonal, and for Girls below the Diagonal $(N=$ I,796).

\begin{tabular}{lcccc}
\hline & I. & 2. & 3. & 4. \\
\hline I. PED by peers & & $.66^{* * *}$ & $.70^{* * *}$ & $-.26 * * *$ \\
2. PED by teachers & $.63 * * *$ & & $.63^{* * *}$ & $-.21 * * *$ \\
3. PED by someone else & $.74^{* * *}$ & $.67^{* * *}$ & & $-.24 * * *$ \\
4. School connectedness & $-.33 * * *$ & $-.32^{* * *}$ & $-.32^{* * *}$ & \\
\hline$* * * p<.001$ & & & &
\end{tabular}

A $2 \times 3$ multivariate analysis of variance (MANCOVA) was performed with age as covariate, sex and immigration status as independent variables, and three types of perceived ethnic discrimination (by peers, teachers, and others) and sense of school connectedness as 
dependent variables. The results of MANCOVA are first presented in Table 3, andthen the univariate analysis are further illustrated in Figures I and 2.

As Table 3 and Figures $I$ and 2 reveal, there were clear statistical effects by family background, and the effect of sex was significant but not substantial. Overall, adolescents with an immigrant background perceived that they had been discriminated more against than adolescents with multicultural background (in which one parent was an immigrant and the other a native). Native adolescents experienced the lowest amounts of discrimination, significantly lower than both the other groups $(p=.001$ for all types of discrimination, except PED by teachers, which was lower only among native adolescents in comparison with those with an immigrant background). They also experienced a significantly higher level of school connectedness than children with an immigrant background, but not than children with a multicultural background $(p=.009)$. The effect of language was not significant when also including family background, and therefore it was excluded in the final analysis.

Furthermore, the multivariate effect for the interaction between family background and sex was also significant (Table 3). Girls with a multicultural background experienced higher levels of discrimination by peers $\left[t_{(160)}=2.84, p<.0 \mathrm{I}, d=.45\right]$ and discrimination by someone else $\left[t_{(159)}=2.19, p<.05, d=.34\right]$ than boys with a multicultural background (Fig. 3). Boys with native and multicultural background showed similar levels of PED by peers, which means that the observed decline in this variable according to family background was due to higher mean values among multicultural girls. Girls with native background were found to have slightly lower scores of PED by teachers $\left[t_{(1337)}=4.19, p<.001, d=.26\right]$. However, they also experienced lower school connectedness $\left[t_{(1373)}=4.45, p<.00 \mathrm{I}, d=.34\right]$ than boys with native background (Fig. 4). 


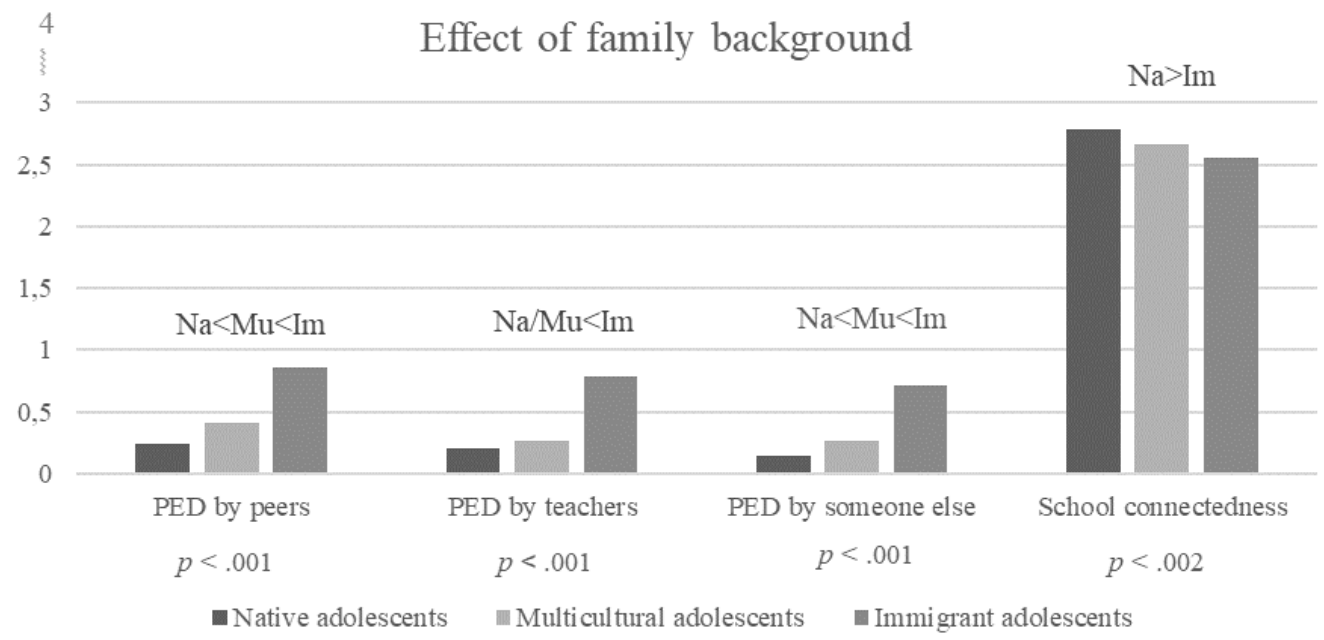

Fig. I.Mean values of the four dependent variables of the study according to immigrant background $(\mathrm{Im}=$ immigrant family, $\mathrm{Mu}=$ multicultural family, and $\mathrm{Na}=$ native family). For statistical details, cf. Table $3(\mathrm{~N}=$ I,588).

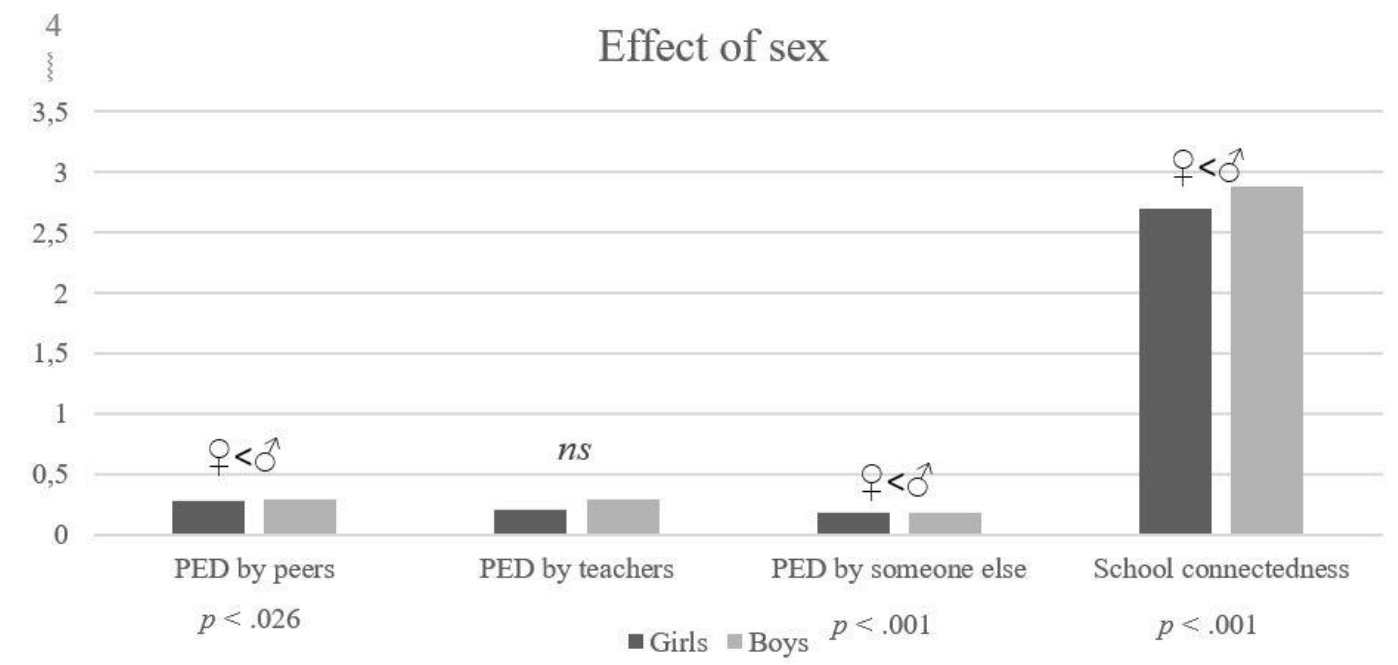

Fig. I.Mean values of the four dependent variables of the study according to sex. For statistical details, cf. Table $3(\mathrm{~N}=1,588)$. 
Table 3

Multivariate Analysis of Variance (MANCOVA) with Family Background and Sex as Independent Variables and PED and School Connectedness as Dependent Variables $(\mathrm{N}=\mathrm{I}, 588)$, cf. Figures I and 2.

列 $\quad F \quad d f \quad p \leq \eta_{p}^{2} \quad \begin{gathered}\text { Group } \\ \text { differences }\end{gathered}$

Effect of Covariate (age)

Multivariate analysis

23.896

$4,1578 \quad .001$

.057

Univariate analyses

PED by peers

PED by teachers

PED by someone else

School connectedness

Effect of Family Background

Multivariate analysis

Univariate analyses

PED by teachers

PED by someone else

School connectedness
31.80

I, 58।

.001

.020

41.29

11.90

66.20

“

$.001 \quad .040$

19.83

$8,3158 \quad .001 \quad .048$

63.40

2,58

$4 I .55$

67.22

6.16

.001

.001
PED by peers

$.074 \mathrm{Im}>\mathrm{Mu}>\mathrm{Na} *$

$.050 \mathrm{Im}>\mathrm{Na} / \mathrm{Mu}$

$.001 \quad .078 \quad \mathrm{Im}>\mathrm{Mu}>\mathrm{Na}$

Effect of Sex 
Multivariate analysis

Univariate analyses

PED by teachers

0.61

11.76

12.83

“

$.001 \quad .008$

$0^{x}>$ ?

Interaction effect Family Background $x$ Sex

Multivariate analysis

$8,3158 \quad .001 \quad .008$

Univariate analyses

PED by peers
PED by teachers

PED by someone else

School connectedness
3.26

2.48

3.34

0.32
2, 1581

.003

$.020 \quad .005$

$.001 \quad .010$

Mu: $९>0^{\pi}$

ns

$\mathrm{Na}: \sigma^{\pi}>$ \%

$* I m=$ immigrant, $\mathrm{Mu}=$ multicultural, $\mathrm{Na}=$ native $\%=$ girl, $\sigma^{\wedge}=$ boy.

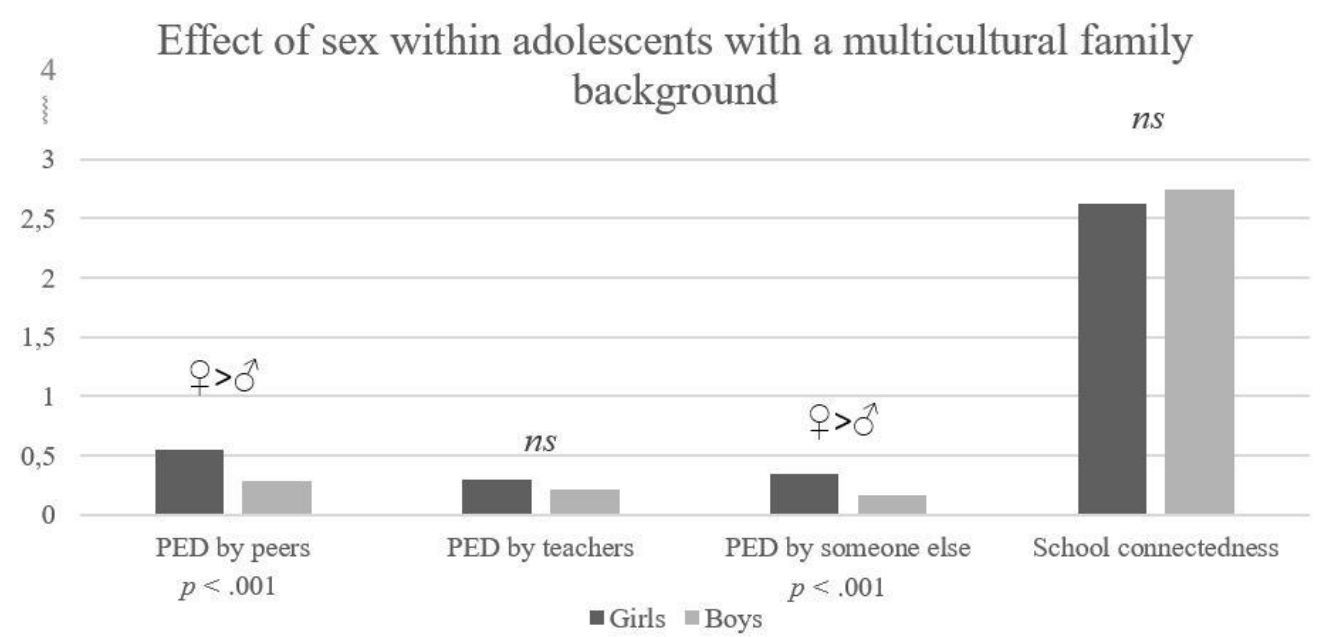

Fig. 3.Mean values of the four dependent variables of the study according to sex within the adolescents with a 


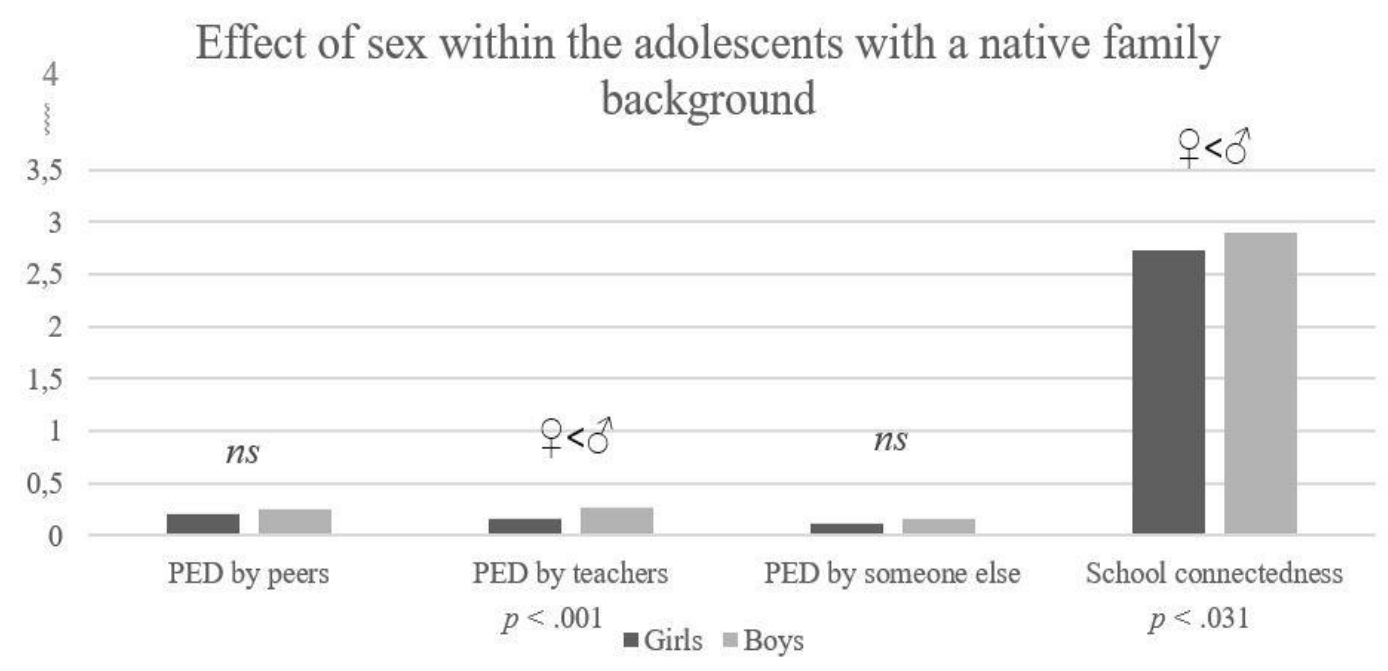

Figure 2. Mean values in four dependent variables of the study according to effect of native family background and sex. For statistical details, cf. Table 3 and the text $(\mathrm{N}=1,588)$.

\section{Discussion}

The current study shows that family background is an essential independent variable that is related to PED and school connectedness, and that it interacts with sex on the dependent variables measured. As expected, adolescents with an immigrant background reported higher levels of PED and lower school connectedness in comparison with those of a multicultural and native background. This finding might be due to the source of discrimination, since PED by teachers has been found to be associated primarily with lower school performance (Benner \& Graham, 20I3), and low school performance has in turn been found to be associated with low school connectedness (Eisenberg et al., 2003). Still, scores for PED by teachers in the current study were quite low, which might mitigate the negative effects of PED by peers (cf. Özdemir \& Stattin, 20I4). Boys reported higher levels of PED by peers and by someone else in comparison with girls, but boys also reported higher levels of school connectedness. However, the effect sizes for sex differences were not substantial. Furthermore, no sex differences were found regarding PED by teachers. Moreover, multicultural girls scored significantly higher on PED by peers and by someone else, which is 
another intriguing result. Compared to multicultural boys, multicultural girls might identify themselves more as immigrants, a fact which may be reflected in more PED by peers.

The finding that adolescents with an immigrant background scored higher on PED are in line with previous research from Finland (Myllyniemi, 2017; Wikström et al., 20I4; Strohmeier et al., 20II) and from other countries (Plenty \& Jonsson, 20I7; Herman, 2004). Moreover, it supports previous research on prejudiced beliefs among adolescents and widespread discrimination in Finland towards immigrants in general and immigrant peers in school (Jaakkola, 2009; Jasinska-Lahti \& Liebkind, 200I; Nshom \& Croucher, 2017; Zacheus et al. 2019). In the present study, boys showed slightly higher levels of PED by peers and by someone else, which is in line with the findings by Assari et al. (2018). Also, in line with previous research (Chiu et al., 2012; Cheng \& Klugman, 2010), adolescents with an immigrant family background scored lower on school connectedness than those with a native family background. Boys reported higher school connectedness than girls, which is supported by the findings by Bottiani et al. (2017).

The study underlines the importance of family background and source of discrimination (i.e. by peers, teachers, or someone else) in terms of gaining a broader perspective on the relationship between the variables. Separating PED by its source might also be a way to identify the negative effects of PED more directly, as the case was in the study by Benner and Graham (20/3). Furthermore, the study also shed light on the situation of multicultural adolescents with one parent being a native, the other an immigrant. The results emphasize that adolescents with a multicultural background should be studied as a separate group. Similar to other European countries, adolescents with immigrant background in Finland are also at risk of experiencing discrimination and negative effects associated with the experience. The fact that multicultural girls experienced more PED might reflect that compared to multicultural boys, they identified themselves more as immigrants (Herman, 2004).

Some limitations of the study should be mentioned. Adolescents who reported their sex as 'other' or 'I prefer not to say' were not included while analyzing sex differences on the dependent variables. Otherwise, they were included in family background analyses. Another 
potential limitation of the study is that adolescents who studied in vocational schools were not included in the study, which might lower the representativeness of the research sample. However, there are not major differences in Finnish secondary schools in terms of learning environment, a fact which decreases this risk. Further research is needed to examine the effect of the source of PED on school connectedness and how these two factors are related with adolescents' social development. In addition to that, longitudinal studies investigating the effect of PED according to its source on proximal processes at the micro-level would provide a better understanding of adolescents' social development. Moreover, PED and school connectedness need to be investigated according to the adolescents' different acculturation approaches (e.g. integration and/or assimilation) to understand the relationship better. Further research on risk factors for adolescents' mental health that are associated with the source of discrimination might strengthen the understanding of the subject. More research is also needed to investigate sex differences within adolescents with a multicultural background. Identifying the association between school connectedness and risk factors in relation to the source of discrimination, taking into account also sex differences in culturally diverse adolescent groups, might potentially enable the development of more effective programs in order to reduce discrimination and foster school connectedness.

\section{References}

Abubakar, A., van de Vijver, F. J., Mazrui, L., Murugami, M., \& Arasa, J. (20I4). Connectedness and psychological well-being among adolescents of immigrant background in Kenya. In R. Dimitrova, M. Bender, \& F. J. R. Van de Vijver (Eds.), Global perspectives on well-being in immigrant families (pp. 95-I I4). New York, NY: Springer.https://doi:10.1007/978-I$\underline{46|4-9| 29-3}$

Assari, S., \& Caldwell, C. (20I7). Darker skin tone increases perceived discrimination among male but not female Caribbean black youth. Children, 4:107.https://doi.org//0.3390/children4120107

Assari, S., Gibbons, F., \& Simons, R. (2018). Perceived discrimination among black youth: an I8-year longitudinal study. Behavioral Sciences, 8:44.https://doi.org// 0.3390/bs8050044

Balfanz, R., Herzog, L., \& Mac Iver, D. J. (2007). Preventing student disengagement and keeping students on the graduation path in urban middle-grades schools: Early identification and effective interventions. Educational Psychologist, 42, 223-235.https://doi.org/10.1080/00461520701621079 
Benner, A. D., \& Graham, S. (20I3). The antecedents and consequences of racial/ethnic discrimination during adolescence: Does the source of discrimination matter? Developmental Psychology, 49, 1602-1613.https://psycnet.apa.org/doi//0.1037/a0030557

Berry, J. W., Phinney, J. S., Sam, D. L., \& Vedder, P. (2006). Immigrant youth: Acculturation, identity, and adaptation. Applied Psychology, 55, 303-332.https://doi.org//0.1 I I I/j.14640597.2006.00256.x

Berry, J. W., Poortinga, Y. H., Breugelmans, S. M., Chasiotis, A., \& Sam D. L., 20I I, Cross cultural psychology, $3^{\text {rd }}$ ed, New York: Cambridge University Press.

Berry, J. W., \& Sabatier, C. (2010). Acculturation, discrimination, and adaptation among second generation immigrant youth in Montreal and Paris. International Journal of Intercultural Relations, 34, 191-207. https://doi.org/10.1016/j.ijintrel.2009.11.007

Bottiani, J. H., Bradshaw, C. P., \& Mendelson, T. (20I7). A multilevel examination of racial disparities in high school discipline: Black and white adolescents' perceived equity, school belonging, and adjustment problems. Journal of Educational Psychology, 109, 532-545.https://psycnet.apa.org/doi/I0.1037/edu0000I55

Bronfenbrenner, U., (2006). The ecology of developmental processes. In W. Demon \& R. M. Lerner (Eds.), Handbook of Child Psychology: Volume I, Theoretical models of human development (6th ed.). Hoboken, NJ: Wiley.

Bronfenbrenner, U. (1994). Ecological models of human development. In T. N. Postlethwaite \& T. Husen (Eds.), International encyclopedia of education (2nd ed., Vol. 3, pp. 568-587). Oxford, UK: Elsevier.

Capps, R., Fix, M., Ost, J., Reardon-Anderson, J., Passel, J. (2005). The health and well-being of young children of immigrants. Urban Institute.

http://webarchive.urban.org/UploadedPDF/3 III 39 ChildrenImmigrants.pdf

Cheng, S., \& Klugman, J. (2010). School racial composition and biracial adolescents' school attachment. The Sociological Quarterly, 5I, I50-178. https://doi.org/I0.1 I I /j.I5338525.2009.01166.x

Chiu, M. M., Pong, S. L., Mori, I., \& Chow, B. W. Y. (20I2). Immigrant students' emotional and cognitive engagement at school: A multilevel analysis of students in $4 \mathrm{I}$ countries. Journal of Youth and Adolescence, $4 I$, |409-|425.https://doi.org//0.1007/s 10964-0|2-9763-x

Contrada, R. J., Ashmore, R. D., Gary, M. L., Coups, E., Egeth, J. D., Sewell, A., ... Chasse, V. (200I). Measures of ethnicity-related stress: Psychometric properties, ethnic group differences, and associations with well-being I. Journal of Applied Social Psychology, 3I, |775-|820.https://doi.org/|0.1 | ||/j.1559-1816.2001.tb00205.x

Contrada, R. J., Ashmore, R. D., Gary, M. L., Coups, E., Egeth, J. D., Sewell, A., ... Chasse, V. (2000). Ethnicity-Related Sources of Stress and Their Effects on Well-Being. Current Directions in Psychological Science, 9, I 36-139. https://doi.org/ | 0.1 I I I/ |467-8721.00078 
Cooper, S. M., Brown, C., Metzger, I., Clinton, Y., \& Guthrie, B. (20I3). Racial discrimination and African American adolescents' adjustment: Gender variation in family and community social support, promotive and protective factors. Journal of Child and Family Studies, 22, 15-29.https://doi.org//0.1007/s 10826-012-9608-y

Delgado, M. Y., Ettekal, A. V., Simpkins, S. D., \& Schaefer, D. R. (20I6). How do my friends matter? Examining Latino adolescents' friendships, school belonging, and academic achievement. Journal of Youth and Adolescence, 45, I I I0-I I 25.https://doi.org//0.1007/s 10964-015-034I-x

Dimitrova, R., Chasiotis, A., \& Van de Vijver, F. (2016). Adjustment outcomes of immigrant children and youth in Europe. European Psychologist, 21 , 150-162.https://doi.org/10.1027/1016-9040/a000246

Dunham, R., \& Wilson, G. (2007). Race, within-family social capital, and school dropout: An analysis of Whites, Blacks, Hispanics, and Asians. Sociological Spectrum, 27, 207-22I. https://doi.org/10.1080/0273217060II23435

Eisenberg, M. E., Neumark-Sztainer, D., \& Perry, C. L. (2003). Peer harassment, school connectedness, and academic achievement. Journal of School Health, 73, 3II-3 |6.https://doi.org/I0.1 I I I/j.1746-I56I.2003.tb06588.x

English, D., Lambert, S. F., \& lalongo, N. S. (20I4). Longitudinal associations between experienced racial discrimination and depressive symptoms in African American adolescents. Developmental Psychology, 50,

I 190-I 1 96.https://psycnet.apa.org/doi/10.1037/a0034703

Fall, A. M., \& Roberts, G. (20I2). High school dropouts: Interactions between social context, self-perceptions, school engagement, and student dropout. Journal of Adolescence, 35, 787-798. https://doi.org/10.1016/j.adolescence.2011.11.004

Finnish Advisory Board on Research Integrity (2012). Responsible conduct of research and procedures for handling allegations of misconduct in Finland. Helsinki, Finland: Finnish Advisory Board on Research Integrity.

Finnish National Agency for Education (P. Karhu, Ed.) (2018). Key figures on general upper secondary school education in Finland (Reports and surveys 2018:13).

https://www.oph.fi/english/publications/2018/key_figures_on_general_upper_secondary education in finland

Gil, A. G., Wagner, E. F., \& Vega, W. A. (2000). Acculturation, familism, and alcohol use among Latino adolescent males: Longitudinal relations. Journal of Community Psychology, 28, 443-458.https://doi.org// 0.1002/I520-6629(200007)28:4\%3C443::AIDJCOP6\%3E3.0.CO;2-A

Gregory, A., \& Weinstein, R. S. (2008). The discipline gap and African Americans: Defiance or cooperation in the high school classroom. Journal of School Psychology, 46, 455-475.https://doi.org/10.1016/j.jsp.2007.09.001 
Herman, M. (2004). Forced to choose: Some determinants of racial identification in multiracial adolescents. Child Development, 75, 730-748.https://doi.org/10.1 I I I/j.I4678624.2004.00703.x

Hernandez, D. J. (2004). Demographic change and the life circumstances of immigrant families. The Future of Children I4, 17-47. https://www.jstor.org/stable/I602792

Hjern, A., Rajmil, L., Bergström, M., Berlin, M., Gustafsson, P. A., \& Modin, B. (20I3). Migrant density and well-being-A national school survey of 15 -year-olds in Sweden. European Journal of Public Health, 23, 823-828.https://doi.org/I0.1093/eurpub/ckt I06

Hughes, J. N., Im, M. H., \& Allee, P. J. (20I5). Effect of school belonging trajectories in grades 6-8 on achievement: Gender and ethnic differences. Journal of School Psychology, 53, 493-507.https://doi.org/10.1016/j.jsp.2015.08.001

Huynh, V. W., \& Fuligni, A. J. (20I0). Discrimination hurts: The academic, psychological, and physical well-being of adolescents. Journal of Research on Adolescence, 20, 916-94I.https://doi.org/10.1 I I I/j.I532-7795.2010.00670.x

Jaakkola, M., (2009). Maahanmuuttajat suomalaisten näkökulmasta. Asennemuutokset 19972007. Helsinki, Finland: City of Helsinki Urban Facts Research Series. https://www.hel.fi/hel2/Tietokeskus/julkaisut/pdf/09 02 _ 19 Tutkimus_Jaakkola.pdf

Jackson, M. I., Kiernan, K., \& McLanahan, S. (20I2). Immigrant-native differences in child health: Does maternal education narrow or widen the gap?. Child Development, 83, I50I-I509. https://doi.org/10.1 I I|/j.|467-8624.20I2.018II.

Jasinskaja-Lahti, I., Liebkind, K., Horenczyk, G., \& Schmitz, P. (2003). The interactive nature of acculturation: Perceived discrimination, acculturation attitudes and stress among young ethnic repatriates in Finland, Israel and Germany. International Journal of Intercultural Relations, 27, 79-97.https://doi.org/10.1016/S0147-I767(02)0006I-5

Joyce, H. D., \& Early, T. J. (20I4). The impact of school connectedness and teacher support on depressive symptoms in adolescents: A multilevel analysis. Children and Youth Services Review, 39, 101-107.https://doi.org/10.1016/j.childyouth.2014.02.005

LaFontana, K. M., \& Cillessen, A. H. (20I0). Developmental changes in the priority of perceived status in childhood and adolescence. Social Development, 19, | 30-|47.https://doi.org/| 0.| | | |/j.|467-9507.2008.00522.x

Liebkind, K., Jasinskaja-Lahti, I., \& Solheim, E. (2004). Cultural identity, perceived discrimination, and parental support as determinants of immigrants' school adjustments: Vietnamese youth in Finland. Journal of Adolescent Research, 19, 635-656.https://doi.org//0.1 177\%2F0743558404269279

Liu, D., Yu, X., Wang, Y., Zhang, H., \& Ren, G. (20I4). The impact of perception of discrimination and sense of belonging on the loneliness of the children of Chinese migrant workers: a structural equation modeling analysis. International Journal of Mental Health Systems, 8:52.https://doi.org/I0.1 I86/1752-4458-8-52 
Lorenzo-Blanco, E. I., Unger, J. B., Oshri, A., Baezconde-Garbanati, L., \& Soto, D. (2016). Profiles of bullying victimization, discrimination, social support, and school safety: Links with Latino/a youth acculturation, gender, depressive symptoms, and cigarette use. American Journal of Orthopsychiatry, 86, 37-48.https://psycnet.apa.org/doi//0.1037/ort00001 I3

McWhirter, E. H., Garcia, E. A., \& Bines, D. (2018). Discrimination and other education barriers, school connectedness, and thoughts of dropping out among Latina/o students. Journal of Career Development, 45, 330-344.https://doi.org//0.II77\%2F0894845317696807

Myllyniemi, S. (2017). Katse tulevaisuudessa: Nuoriso barometri 2016.(Report No. 56). Opetusja kulttuuriministeriö, Valtion nuorisoneuvosto, Nuorisotutkimusseura ja tekijät. https://tietoanuorista.fi/wpcontent/uploads/2017/03/Nuorisobarometri_2016_WEB.pdf

Nadal, K. L. (20I I). The Racial and Ethnic Microaggressions Scale (REMS): Construction, reliability, and validity. Journal of Counseling Psychology, 58, 470-480.https://psycnet.apa.org/doi/10.1037/a0025/93

Niehaus, K., Irvin M.J., Rogelberg, S. (2016). School connectedness and valuing as predictors of high school completion and postsecondary attendance among Latino youth. Contemporary Educational Psychology, 44, 54-67. https://doi.org/10.1016/j.cedpsych.2016.02.003

Noh, S., \& Kaspar, V. (2003). Perceived discrimination and depression: Moderating effects of coping, acculturation, and ethnic support. American Journal of Public Health, 93, 232-238.https://doi.org//0.2105/AJPH.93.2.232

Nshom, E., \& Croucher, S. (2017). Perceived threat and prejudice towards immigrants in Finland: A study among early, middle, and late Finnish adolescents. Journal of International and Intercultural Communication, 10, 309-323.https://doi.org/10.1080/17513057.2017.1312489

OECD. (20I8). Working together: Skills and labour market integration of immigrants and their children in Finland, Paris, France: OECD Publishing.https://doi.org//0.1787/9789264305250-en

OECD. (20I7). PISA 2015 results (Volume III): Students well-being. Retrived from: https://www.oecd-ilibrary.org/education/pisa-20I5-results-volume-iii/students-sense-ofbelonging-by-immigrant-background_9789264273856-table I25-en

Oldfield, J., Humphrey, N., \& Hebron, J. (2016). The role of parental and peer attachment relationships and school connectedness in predicting adolescent mental health outcomes. Child and Adolescent Mental Health, 2I, 21-29.https://doi.org/ I0.1 I I //camh.12108

O’Neel, C., \& Fuligni, A. (2013). A longitudinal study of school belonging and academic motivation across high school. Child Development, 84, 678-692.https://doi.org/10.1III/j.1467-8624.2012.01862.x 
Özdemir, M., \&Bayram Özdemir, S. (2017). The role of school context in adolescents' attitudes towards immigrants and inter-ethnic friendships. In: E. Lundberg (Ed.), The mechanisms of tolerance: An anthology.Stockholm: The Living History Forum 7.

Özdemir, S. B., \& Stattin, H. (20I4). Why and when is ethnic harassment a risk for immigrant adolescents' school adjustment? Understanding the processes and conditions. Journal of Youth and Adolescence, 43, I252-1265.https://doi.org/10.1007/s 10964-013-0038-y

Pachter, L. M., Bernstein, B. A., Szalacha, L. A., \& Coll, C. G. (20I0). Perceived racism and discrimination in children and youths: An exploratory study. Health \& Social Work, 35, 6I-69. https://doi.org//0.1093/hsw/35.1.6I

Plenty, S., \& Jonsson J. O. (2017). Social exclusion among peers: The role of immigrant status and classroom immigrant density. Journal of Youth and Adolescence, 46, I275-1288. https://doi.org// 0.1007/s10964-016-0564-5

Spencer, M. B., Dupree, D., \& Hartmann, T. (1997). A phenomenological variant of ecological systems theory (PVEST): A self-organization perspective in context. Development and Psychopathology, 9, 817-833.https://doi.org/I0.1017/S0954579497001454

Statistics Finland (2019). Number of persons with foreign background exceeded 400,000. http://www.stat.fi/til/vaerak/2018/02/vaerak_2018_02_2019-06-I9_tie_00I_en.html

Strohmeier, D., Kärnä, A., \& Salmivalli, C. (20I I). Intrapersonal and interpersonal risk factors for peer victimization in immigrant youth in Finland. Developmental Psychology, 47, 248-258.https://psycnet.apa.org/doi//0.1037/a0020785

Taguma, M., Shewbridge, C., Huttowa, J., \& Hoffman, N. (2009). OECD reviews of migrant education: Norway 2009. https://www.oecd.org/education/school/43723539.pdf

Uslu, F., \& Gizir, S. (2017). School belonging of adolescents: The role of teacher-student relationships, peer relationships and family involvement. Educational Sciences: Theory and Practice, 17, 63-82.https://doi.org/10.12738/estp.2017.1.0104

Vedder, P. H., \& Horenczyk, G. (2006). Acculturation and the school. In D. L. Sam \& J. W. Berry (Eds.), The Cambridge handbook of acculturation psychology (pp. 419-438). New York: Cambridge University Press.https://psycnet.apa.org/doi/I0.1017/CBO97805 I|48989|.031

Wang, M. T., \& Fredricks, J. A. (2014). The reciprocal links between school engagement, youth problem behaviors, and school dropout during adolescence. Child Development, 85, 722-737.https://doi.org/10.1III/cdev.12138

Whitbeck, L. B., Hoyt, D. R., McMorris, B. J., Chen, X., \& Stubben, J. D. (200I). Perceived discrimination and early substance abuse among American Indian children. Journal of Health and Social Behavior,42, 405-424.http://www.jstor.org/stable/3090I87

Wikström, K., Haikkola, L., \& Laatikainen, T. (20I4). Maahanmuuttajataustaisten nuorten terveys ja hyvinvointi: Tutkimus pääkaupunkiseudun somali-ja kurditaustaisista nuorista. 
http://www.julkari.fi/bitstream/handle/I0024/II6I99/URN_ISBN_978-952-302-2I26.pdf?sequence $=1$

Wong, C. A., Eccles, J. S., \& Sameroff, A. (2003). The influence of ethnic discrimination and ethnic identification on African American adolescents' school and socioemotional adjustment. Journal of Personality, 7/, I 197-1232. https://doi.org//0.1 I I // 467$\underline{6494.7106012}$

Zacheus, T., Kalalahti, M., Varjo, J., Saarinen, M., Jahnukainen, M., Mäkelä, M. L., \& Kivirauma, J. (2019). Discrimination, harassment and racism in Finnish lower secondary schools. Nordic Journal of Migration Research, 9, 81-98.https://doi.org/10.2478/njmr-2019-0004 